\title{
Association of ecstasy seizure rates with district Human Development Index in the municipality of São Paulo, Brazil, from 2000 to 2007
}

\author{
Silvio Fernandes Lapachinske", Regina Lucia de Moraes Moreau, ${ }^{2, *}$ \\ ${ }^{1}$ Regional Superintendence of the Federal Police in São Paulo, ${ }^{2}$ Department of Clinical and Toxicological Analysis, \\ Faculty of Pharmaceutical Sciences, University of São Paulo
}

\begin{abstract}
This study aimed to analyze whether ecstasy consumption is associated with the socioeconomic status in the Municipality of São Paulo, Brazil, from 2000 to 2007. We used an official, reliable and unbiased source supplied by the Department of Narcotics of the State of São Paulo (Denarc) database and the Human Development Index of the districts (HDId) where the seizures occurred. A Spearman correlation test between the average number of ecstasy seizures per million of inhabitants with the HDId was used. There were 190 seizures (totaling 47,934 tablets) spread out in 53 of the 96 districts and 51.6\% were concentrated in only 8 districts. The higher rates of ecstasy seizures were directly associated with districts with high HDId that confirmed the association of ecstasy consumption with the socioeconomic status. Itaim-Bibi, Jardim Paulista and Moema were the top three districts with the highest HDId. In these districts, the number of tablets per seizure ranged from as few units to thousands, revealing that not only consumption but also traffic coexist at the same place. Districts with many nightclubs can also influence the incidence of seizures. This knowledge can be useful to help the police from other Brazilian cities to combat ecstasy trafficking.
\end{abstract}

Uniterms: Ecstasy/consumption. Illegal drugs/consumption. Illegal drugs/traffic. Illegal drugs/users. São Paulo/city/use of illegal drugs. Socioeconomic status/use of illegal drugs.

Este estudo teve como objetivo analisar se o consumo de ecstasy está associado com o nível socioeconômico no Município de São Paulo, Brasil, de 2000 a 2007. Nós usamos uma fonte oficial, confiável e imparcial fornecida pelo banco de dados do Departamento de Narcóticos do Estado de São Paulo (Denarc) e o Índice de Desenvolvimento Humano dos distritos (IDHd), onde as apreensões ocorreram. O teste de correlação de Spearman entre o número médio de apreensões de ecstasy por milhão de habitantes e o IDHd foi utilizado. Houve 190 apreensões (totalizando 47.934 comprimidos) distribuídas em 53 dos 96 distritos e 51,6\% concentraram-se em apenas 8 distritos. As maiores taxas de apreensão de ecstasy foram diretamente associadas com distritos com alto IDHd, o que confirmou a associação do consumo de ecstasy com o nível socioeconômico. Itaim Bibi, Jardim Paulista e Moema, distritos como os maiores IDHd, foram os três primeiros colocados. Nesses distritos, o número de comprimidos por apreensão variou de poucas unidades a milhares, revelando que não somente o consumo como também o tráfico coexiste no mesmo local. Distritos com muitas casas noturnas também podem influenciar a incidência de apreensão. Esse conhecimento pode ser útil no auxílio à polícia de outras cidades brasileiras no combate ao tráfico de ecstasy.

Unitermos: Ecstasy/consumo. Drogas ilegais/consumo. Drogas ilegais/tráfico. Drogas ilegais/usuários. São Paulo/cidade/uso de drogas ilegais. Nível sócioeconomico/uso de drogas ilegais.

\footnotetext{
"Correspondence: R. L. M. Moreau. Departamento de Análises Clínicas e Toxicológicas, Faculdade de Ciências Farmacêuticas, Universidade de São Paulo. Av. Professor Lineu Prestes, 580 - Bloco 13B, 05508-900 - São Paulo SP, Brasil. E-mail: rlmoreau@usp.br
} 


\section{INTRODUCTION}

Ecstasy, the common name of 3,4-methylenedioxymethamphetamine or MDMA, is a synthetic psychoactive drug with both stimulant and hallucinogenic properties that usually comes in tablet form in different dimensions, colors and logos. It has become popular among younger adults at raves, dance parties and nightclubs due to its 3-E-effect: energy, empathy and euphoria (Schwartz, Miller, 1997; Kalant, 2001). Ecstasy users are primarily motivated by the energetic and euphoric effects they expect from it as they can dance all night and stay in high spirits. Other motives reported are being closer to others, making flirting easier, having better sex and forgetting problems (Almeida, Silva, 2003; Ter Bogt, Engels, 2005).

Although MDMA was first synthesized at Merck in 1912 (Freudenmann, Öxler, Bernschneider-Reif, 2006) its use as recreational drug was virtually unknown in Europe before the late 1980s but increased rapidly during the 1990s (EMCDD, 2010). In São Paulo, Brazil, the first significant shipments of ecstasy were noticed in 1994 (Almeida, Silva, 2003).

The United Nations Office on Drugs and Crime (UNODC) annually publishes the World Drug Report, which gathers the main data and trends analyses on production, trafficking and consumption of illegal drugs worldwide. MDMA and its analogues as MDA (3,4-methylenedioxyamphetamine) and MDEA/MDE (3,4-methylenedioxyethylamphetamine) are referred as ecstasy-group substances. According to the 2009 World Drug Report, worldwide ecstasy-group substances seizures began to rise in the $90 \mathrm{~s}$, peaked in 2004, fell around $30 \%$ in 2005/2006 and peaked again in 2007 . Brazilian ecstasy-group tablets seizures also showed a similar pattern: an increase in 2000, a peak in 2004, a significant drop in 2006 and a dramatic rise to 211,145 tablets in 2007, placing Brazil, for the first time, in the twenty second position for countries with highest seizures of ecstasy-group substances (UNODC, 2009).

To gather information on ecstasy users in Brazil and specifically in the city of São Paulo surveys such as self-report questionnaires (Almeida, Silva, 2003; Almeida, Silva, 2005), interviews with users (Battisti et al., 2006) and also online questionnaires on a website set up specifically for this purpose (Almeida, Bizeto, Silva, 2007; Almeida, Garcia-Mijares, Silva, 2009) were carried out. As the source of information came from volunteers who chose to participate of their own free will and the online sample could have also been limited to individuals who had access to the internet, these studies may not be a representative of Brazilian ecstasy users. However, in all of these studies very similar characteristics of the consumers were found: the majority were young male members of high socioeconomic classes, with a good educational background, currently employed or studying and polydrug users. Moreover, these results also were coincident with data found in other countries (Degenhardt, Barker, Topp, 2004; Ter Bogt, Engels, 2005). Therefore, socioeconomic status may be a pattern of ecstasy users.

The price paid for an ecstasy pill is another factor that could contribute to its use by the upper class. It varies from $\mathrm{R} \$ 25$ to $\mathrm{R} \$ 50$ (equivalent to US\$8 to US\$16), which is expensive compared with US\$9.00 per gram of cocaine and US\$2.30 for a crack rock (Battisti et al., 2006; Almeida, Garcia-Mijares, Silva, 2009). Ecstasy users normally took 1-2 pills per occasion once to three times a month according to Brazilian surveys, therefore, the amount spent per month may vary from $\mathrm{R} \$ 25$ to $\mathrm{R} \$ 300$. This frequency of use and dosage of pills per occasion is also similar to that found in others studies (Degenhardt, Barker, Topp, 2004; Ter Bogt, Engels, 2005). Gender differences in pattern of ecstasy use have recently been reported: males normally consume 2-3 pills on one typical occasion whereas females normally consume 1 pill (Ogeil, Rajaratnam, Broadbear, 2013).

This study investigated whether in the city of São Paulo the ecstasy consumption is associated with the socioeconomic status but this time using a reliable and unbiased source of information on ecstasy seizures. We used the database supplied by the Department of Narcotics of the State of São Paulo (Denarc), which is responsible for drug enforcement in the municipality of São Paulo. We related the HDI of the district where the ecstasy tablets were seized with the ecstasy seizures rates as we worked on the hypothesis that the consumption of ecstasy are more frequent in districts of high socioeconomic level.

The Human Development Index (HDI) is commissioned by the United Nations Organization to assess a country's socioeconomic achievements in three basic aspects of human development: longevity, knowledge, and a decent standard of living. Longevity is measured by life expectancy at birth; knowledge by measuring a combination of the adult literacy rate and the rate of enrollment to primary, secondary, and tertiary schools; and standard of living by the Gross Domestic Product (GDP) per capita, purchasing power parity US dollars. According to the HDI, the countries may have a low $(<0.500)$, intermediate $(0.500$ to 0.799$)$ or high $(\geq 0.800)$ development status (UNDP, 2005).

Although HDI is used to rank countries, the Municipality of São Paulo calculated in 2002 the HDI for 
its 96 districts using data from the year 2000. The 3 general dimensions (longevity, knowledge, and a decent standard of living) were the same, but some standard indicators were changed. The infant mortality rate was used instead of life expectancy at birth to measure longevity; a combination of the literacy rate and the average years of study for the householder were considered for knowledge and the income of head of family for each district for standard of living (Prefeitura de São Paulo, 2012a).

\section{MATERIAL AND METHODS}

We had access to Denarc's database of occurrences involving ecstasy tablets possession in the city of São Paulo from the period of 2000-2007. Information such as the number of tablets, date and address of each seizure was obtained. When the quantity of the drug was registered in weight, the value of $200 \mathrm{mg}$ was considered as average mass for one tablet to standardize all the results in number of tablets. By means of the address where the seizure was registered it was possible to identify the corresponding district for each seizure.

An annual weighted average of the number of seizures in each district using the population for each year as the weight, was calculated from data obtained from the census and estimated population from 2000 to 2007 (Prefeitura de São Paulo, 2012b). These scores were converted into seizures per million inhabitants to standardize the data and to check if the number of inhabitants per district could influence the seizure rates.

The correlation between the average rate of seizures calculated per million of inhabitants and the Human Development Index calculated by the Municipality of São Paulo for each district (HDId) for the year 2000 (Prefeitura do Município de São Paulo, 2002) was studied using the Spearman correlation coefficient (rho).

As there was a large difference in number of districts per range of HDId i.e. 6 districts in high $(\geq 0.800) 52$ in intermediate $(0.500$ to 0.799$)$ and 38 in low $(<0.500)$ the average number of seizures per district was also calculated in order to standardize the data for comparison.

\section{RESULTS}

There were 190 seizures totaling 47,934 tablets in the municipality of São Paulo from 2000 to 2007 (Figure 1A). The number of tablets per seizure ranged from 1 to 4,321 , with an average of 251, a standard deviation of 572 and a median of 48 . Despite the large range of the number of tablets per seizure (from 1 to 4,321), most of seizures were up to 100 tablets.
The 190 seizures were spread out in 53 of the 96 districts and $51.6 \%$ were in 8 districts only. When the districts were ranked according to the highest percentage of seizures, as shown in Figure 1B, the top three districts, Itaim-Bibi, Jardim Paulista and Moema, were also the ones with the highest HDId $(\geq 0.800)$. In these districts, the number of tablets per seizure ranged from as few units $(35.2 \%)$ to dozens $(37.0 \%)$, hundreds $(18.5 \%)$ and even thousands $(9.3 \%)$. When ranked according to the highest number of seizures per million inhabitants, as showed in Figure $1 \mathrm{C}$, the 8 top ranking districts were also similar.
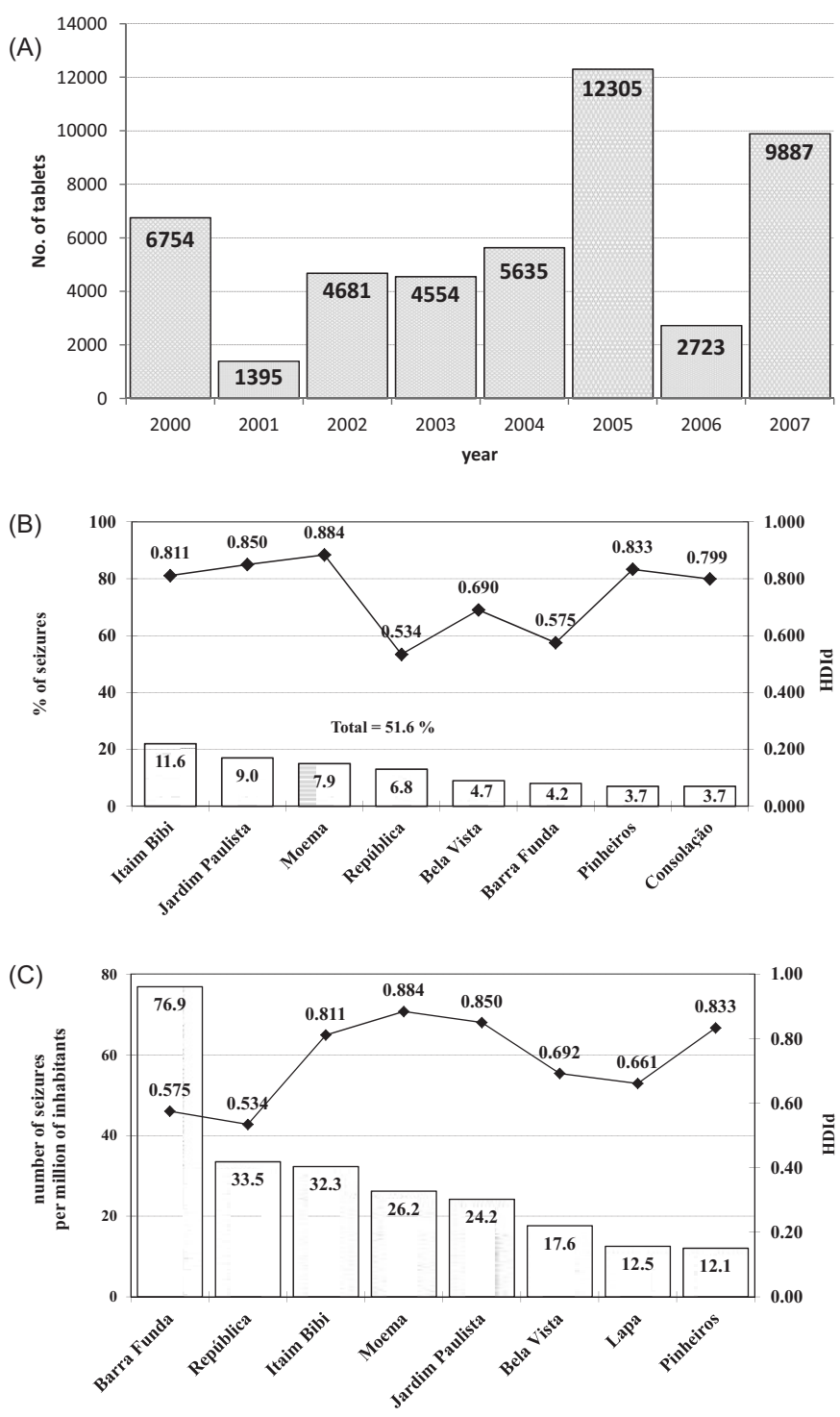

FIGURE 1 - Ecstasy tablets seized in the municipality of São Paulo from 2000 to 2007. (A) Total number per year; (B) Top ranking districts according to percentage of seizures and their corresponding HDI (HDId); (C) Top ranking districts according to number of seizures per million of inhabitants and their corresponding HDI (HDId). 
Due to the fact that most of the seizures occurred in only $8.3 \%$ of all districts, the number of inhabitants per district did not influence the result of the districts that had the highest number of seizures as the 8 top ranking districts were similar in both situations. The only difference observed was a change in the ranking of Barra Funda and República districts which came to take the first and second place because of their lower number of inhabitants (Figures $1 \mathrm{~B}$ and $1 \mathrm{C}$ ).

The average number of seizures per district showed that the districts with high HDId (only 6) had by far the highest rates, i.e. 10.50, compared with 2.19 for intermediate ( 52 districts) and 0.34 for those with lower HDId (38 districts). No seizures were registered in the 8 districts with the lowest HDId $(<0.42)$.

The Spearman test showed a positive correlation between the incidence of ecstasy seizures per million of inhabitants and HDId (rho=0.7013; $<<0.001 ; n=53$ ) (Figure 2).

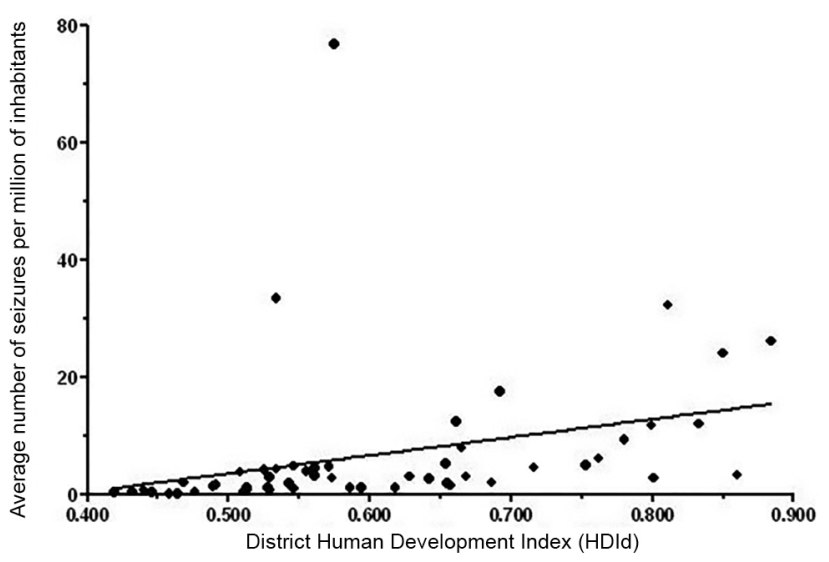

FIGURE 2 - Spearman correlation between average number of seizures per million of inhabitants and District Human Development Index (HDId) (rho $=0.7013 ; \mathrm{p}<0.01 ; \mathrm{n}=53)$.

\section{DISCUSSION}

São Paulo was chosen to be the target city of our study as it is the most populated in Brazil, in the Americas and the Southern Hemisphere. Furthermore it plays an influential role in the World Global scenario. Therefore, it was not surprising that our results showed that the number of ecstasy tablets seized in the municipality of São Paulo from 2000 to 2007 followed the same pattern as Brazil and the rest of the world by dropping sharply in 2006 and recovering in 2007 (Figure 1A).

One of the reasons for the world decrease of ecstasy seizures in 2006 could be explained by the lack of the main MDMA precursor named 3,4-methylendioxyphenyl- 2-propane or 3,4-MDP-2-P, also known as PMK. Up to 2004, large quantities of PMK were smuggled into major European Union ports. Greater cooperation between the Chinese and European authorities appeared to have reduced this flow. According to Europol, illicit PMK prices rose in the European Union in 2005 and 2006, indicating an emerging shortage on the market. Due to the lack of PMK, the number of European seizures of ecstasy precursors was affected. Over the period 20012005 , it accounted for $60 \%$ of global ecstasy precursor seizures whereas in 2005, this proportion fell to $32 \%$ and consequently, the world ecstasy production fell in 2006 (UNODC, 2007).

As the ecstasy tablets seized in Brazil come from European countries, mainly the Netherlands (UNODC, 2007), they are subjected to fluctuations in the international market and suffer the consequences of measures taken in Europe to combat drugs and control their precursors. The effects of the fluctuations in the illegal supply of ecstasy in Brazil were also reflected by the number of tablets seized in major cities like São Paulo.

The HDId influence on the incidence of seizures was clearly revealed in our findings which showed that districts with high HDId were directly associated with higher rates of ecstasy seizures, the incidence of seizures in these districts was proportionally much higher compared to the others with lower HDId and there were no seizures registered in the districts with the lowest HDId $(<0.42)$. These results confirmed our hypothesis that the consumption of ecstasy is more frequent in districts with high socioeconomic levels and are in line with others studies that had also found that ecstasy users come from upper classes (Almeida, Silva, 2003; Almeida, Silva, 2005; Battisti et al., 2006; Almeida, Bizeto, Silva, 2007; Almeida, Garcia-Mijares, Silva, 2009).

Our results also showed that districts with many nightclubs, pubs and so on, can influence the incidence of seizures. This explains why Morumbi $(\mathrm{HDId}=0.860)$ and Alto de Pinheiros (HDId=0.801) were out of the top ranking listing as these two remaining districts with high HDId are basically residential areas where there are only some nightclubs. On the contrary, Barra Funda and República that were not typically high HDId districts had higher rates probably due to the existence of a high number of nightclubs. These results confirmed that the well-known typical settings of ecstasy use are dance clubs and rave parties (Gahlinger, 2004; Maxwell, 2005). Data from a Brazilian survey also showed that $95.2 \%$ of 1.140 participants answered that party and/or club environment led to the consumption of ecstasy (Almeida, GarciaMijares, Silva, 2009). Similar results were found in the 
city of São Paulo from interviews with ecstasy users that point to nightclubs and rave parties as the main context of use (Battisti et al., 2006). Another study, in the city of São Paulo, enrolling 52 ecstasy users of both genders showed that the drug was usually consumed in the company of several people $(63 \%)$ in contexts related to night leisure, such as rave parties (78.8\%), dancing clubs $(69.2 \%)$ and parties (53.8\%) (Almeida, Silva, 2003). In addition, a significant difference comparing ecstasy users with nonusers in relation to the frequency of rave attendance was reported: $65.3 \%$ of users go to raves more than once a month in contrast to only $16.7 \%$ of non-users (Almeida, Silva, 2005). A concerning fact from a recent study drew the attention to the possibility that participants were dependent on club drugs and found that severe dependence was more likely among those who reported recent use of ecstasy (Ding et al., 2013).

Another relevant finding in our study was that not only consumption but also traffic of ecstasy may be taking place mainly in those districts with the higher HDId as the range of the number of tablets per seizure was visibly wider (from a few units to thousands) and followed a distinct pattern in the majority of the 190 seizures that were up to 100 tablets per seizure. According to the current Brazilian legislation (Law number 11.343, from August, $23,2006)$ one of the indicators to distinguish dealers from users is the quantity of drugs seized. Therefore an ecstasy user can be characterized as carrying a few units of tablets while a dealer as carrying larger quantities. This result is also consistent with a previous study carried out in the city of São Paulo, which found that the majority of ecstasy users acquired the drug in places such as rave parties $(59.2 \%)$ and parties $(44.9 \%)$ which were the same type of location where the drug was consumed. Moreover ecstasy pills were mainly purchased from friends or acquaintances (53.1\%) (Almeida, Silva, 2003).

We can suggest that ecstasy final dealers and users are part of the same group of friends as they coexist in the same settings. It is probable that the dealers' sociodemographic characteristics are similar to the consumers': young males from a high socioeconomic status having a good educational background. The behavior of the ecstasy dealer is completely different from other drug dealers, for example, cocaine. In most cases, in order to buy the drug, users go to specific places like crackhouses which are usually in slums and supervised by soldier dealers.

To summarize, the results of this study showed that the higher rates of ecstasy seizures is associated with high HDId in the city of São Paulo, the consumption and traffic coexist at the same settings and the presence of nightclubs influenced the incidence of seizures. This knowledge can be useful to help the police from other Brazilian cities to combat trafficking.

\section{ACKNOWLEDGMENTS}

The authors wish to thank the Head of Command of the Division of Intelligence and Police Support (DIAP) of the Department of Narcotics of the State of São Paulo (Denarc) for authorizing the access to the database.

\section{REFERENCES}

ALMEIDA, S.P.; BIZETO, J.; SILVA, M.T.A. Análise de comentários espontâneos elaborados por usuários de ecstasy em pesquisa on-line. Rev. Panam. Salud Publica, v.22, n.6, p.389-395, 2007.

ALMEIDA, S.P.; GARCIA-MIJARES, M.; SILVA, M.T.A. Patterns of ecstasy use and associated harm: results of a Brazilian online survey. Subst. Use Misuse, v.44, n.14, p.2014-2027, 2009.

ALMEIDA, S.P.; SILVA, M.T.A. Characteristics of ecstasy users in São Paulo, Brazil. Subst. Use Misuse, v.40, n.3, p.395-404, 2005.

ALMEIDA, S.P.; SILVA, M.T.A. Ecstasy (MDMA): effects and patterns of use reported by users in São Paulo. Rev. Bras. Psiquiatr., v.25, n.1, p.11-17, 2003.

BATTISTI, M.C.; NOTO, A.R.; NAPPO, S.; CARLINI, E.A. A profile of Ecstasy (MDMA) use in São Paulo, Brazil: an ethnographic study. J. Psychoactive Drugs, v.38, n.1, p.13-18, 2006.

DEGENHARDT, L.; BARKER, B.; TOPP, L. Patterns of ecstasy use in Australia: findings from a national household survey. Addiction, v.99, n.2, p.187-195, 2004.

DING, Y.; HE, N.; SHOPTAW, S.; GAO, M.; DETELS, R. Severity of club drug dependence and perceived need for treatment among a sample of adult club drug users in Shanghai, China. Soc. Psychiatry Psychiatr. Epidemiol., v.49, n.3, p.395-404, 2014.

EUROPEAN MONITORING CENTRE FOR DRUGS AND DRUG ADDICTION. EMCDD. Annual report 2010: the state of the drugs problem in Europe. Lisbon, 2010. p.50. 
FREUDENMANN, R.W.; ÖXLER, F.; BERNSCHNEIDERREIF, S. The origin of MDMA (ecstasy) revisited: the true story reconstructed from the original documents. Addiction, v.101, n.9, p.1241-1245, 2006.

GAHLINGER, P.M. Club drugs: MDMA, gammahydroxybutyrate (GHB), Rohypnol, and ketamine. Am. Fam. Physician. v.69, n.11, p.2619-2626, 2004.

KALANT, H. The pharmacology and toxicology of "ecstasy" (MDMA) and related drugs. CMAJ., v.165, n.7, p.917-928, 2001.

MAXWELL, J.C. Party drugs: properties, prevalence, patterns, and problems. Subst. Use Misuse, v.40, n.9-10, p.12031240, 2005.

OGEIL, R.P.; RAJARATNAM, S.M.; BROADBEAR, J.H. Male and female ecstasy users: differences in patterns of use, sleep quality and mental health outcomes. Drug Alcohol Depend., v.132, n.1-2, p.223-230, 2013.

PREFEITURA DE SÃO PAULO. Índice de Desenvolvimento Humano (IDH). Available at: $<$ http://www9.prefeitura. sp.gov.br/sempla/mm/mapas/intro_idh.pdf $>$ Accessed on: 13 Dec. 2012a.

PREFEITURA DE SÃO PAULO. População recenseada e estimada. Município de São Paulo, Subprefeituras e Distritos Municipais. 1980, 1991, 2000 a 2007 e 2010. Available at: $<$ http://www9.prefeitura.sp.gov.br/sempla/ $\mathrm{md} / \mathrm{mostra}$ _tabela.php? cod_subtema $=$ dem\&nome tab $=$ demografia $1 \&$ partes $=1>$ Accessed on: 13 Dec. $2012 b$.
PREFEITURA DO MUNICÍPIO DE SÃO PAULO. Desigualdade em São Paulo: o IDH. São Paulo: Secretaria de Desenvolvimento, Trabalho e Solidariedade, Prefeitura do Município de São Paulo, 2002. Available at http://www2. uol.com.br/aprendiz/n_noticias/imprescindivel/id150802. doc. Accessed on: 13 Dec. 2012.

SCHWARTZ, R.H.; MILLER, N.S. MDMA (ecstasy) and the rave: a review. Pediatrics, v.100, n.4, p.705-708, 1997.

TER BOGT, M.T.F.; ENGELS, R.C. "Partying" hard: party style, motives for and effects of MDMA use at rave parties. Subst. Use Misuse, v.40, n.9-10, p.1479-1502, 2005.

UNITED NATIONS DEVELOPMENT PROGRAMME. UNDP. Human development report 2005: international cooperation at a crossroads: aid, trade and security in an unequal world. New York: United Nations, 2005. 212 p.

UNITED NATIONS OFFICE ON DRUGS AND CRIME. UNODC. World drug report 2009. New York: United Nations, 2009. p.140-141.

UNITED NATIONS OFFICE ON DRUGS AND CRIME. UNODC. World drug report 2007. New York: United Nations, 2007. p.133-145.

Received for publication on $19^{\text {th }}$ June 2013 Accepted for publication on $17^{\text {th }}$ December 2013 